\title{
Competitiveness of Small and Medium Businesses and Competitive Pressure in the Manufacturing Industry
}

\author{
Alexander Kalita \\ Doctoral student, Doctoral School of Management, akalita.hse@gmail.com \\ Alexander Chepurenko \\ Professor and Head, Department of Sociology, achepurenko@hse.ru
}

National Research University Higher School of Economics, 11, Myasnitskaya str., 101000, Moscow, Russian Federation

\begin{abstract}
$\mathrm{I}$ $\mathrm{n}$ this paper, the relationship between internal competitiveness factors and the perception of Russian SMEs' level of competitiveness are examined, based on a secondary analysis of the RuFIGE (Russian enterprises in the global economy) survey data obtained in 2014 by 1,677 Russian industrial small and medium-sized enterprises (SMEs).

It comes out that neither the high technological level, the introduction of the CRM system, nor the availability of external financing are sufficient for Russian manufacturing SMEs to feel competitive on the global market. From the other side, those manufacturing SMEs whose main
\end{abstract}

\section{Keywords:}

Firm competitiveness; competitive pressure; small and medium-sized enterprises; manufacturing; RuFIGE. competitors are domestic enterprises, count neither the technological level nor the presence of a CRM system to be necessary factors for competitiveness.

Further, there are different "weight categories" among Russian manufacturing SMEs. SME owners, who work only on local markets, are immune to competition from large foreign companies and consider Russian firms similar to their own as their main competitors. Those who work on the whole Russian market feel a great amount of competitive pressure from foreign manufacturers.

The conclusion provides theoretical and practical recommendations on the results of this study.
Citation: Kalita A., Chepurenko A. (2020)

Competitiveness of Small and Medium Businesses and Competitive Pressure in the Manufacturing Industry. Foresight and STI Governance, vol. 14, no 2, pp. 36-50. DOI: $10.17323 / 2500-2597.2020 .2 .36 .50$ 
$\mathrm{F}$ or a long time, studying companies' competitiveness mainly amounted to analyzing various internal factors [Hoskisson et al., 1999; Furrer et al., 2008] and the external market environment [Hitt et al., 2016]. The analysis was mostly based on data from developed countries, with only a much smaller number of studies devoted to transitional (transformation) economies [Hitt et al., 2004; Aidis et al., 2008; Meyer, Peng, 2016]. Also, international researchers tended to focus on key factors affecting competitive advantages of large corporations, so their findings cannot be fully applied to better understand the specifics of small and medium enterprises (SMEs) [Man et al., 2002; Caloghirou et al., 2004; Hurley, 2018; Lafuente et al., 2019].

Competitiveness is usually seen as a central element when corporate strategies are developed [Barney, 1991; Porter, 1980; Hitt et al., 2016]. Furthermore, it is assumed that strategic decision-makers are well aware of the state of the competitive environment in the industry and can assess its effect upon the company's activities [Porac et al., 1989; Porac, Thomas, 1990]. However, most SMEs do not have any formalized strategies at all and their assessment of the competitive environment essentially amounts to a subjective assessment of its pressure upon a firm.

The need to analyze competitiveness factors arises from the need to achieve adequate product quality, productivity, and operational efficiency as well as meet customers' and business partners' requirements [Raymond et al., 2015, 2016]. Not only is the ability to network with strategic partners of critical importance here, but also being able to systematically adapt the organization's activities to match the changing market environment [Díaz-Chao et al., 2016; Lafuente et al., 2019].

How important is it for Russian SMEs to take their competitiveness into account? There are a number of empirical Russian studies of internal and external competitiveness factors. Their authors used various techniques to assess the competitive positions of Russian manufacturing enterprises [Gurkov et al., 2005; HSE, 2008, 2014; Shakina et al., 2017; Alimova, 2017; Golikova, Kuznetsov, 2017]. However, the impact the objective factors affecting SMEs' competitiveness make on SME managers' subjective assessment of the competitive pressure their companies experience remains poorly understood.

This paper analyzes the above relationship using the Russian manufacturing industry as an example, taking into account competitive pressure from domestic and foreign manufacturers.

\section{Literature Review}

No universally accepted definition of SMEs' competitiveness has yet been suggested in the academic literature [Man et al., 2002; Díaz-Chao et al., 2016; Lafuente et al., 2019]. We define it as the ability to consciously manage the potential (technological level of products, application of information and communication technologies (ICT) and strategic partnerships, access to external funding and product markets) to support and strengthen key financial and economic indicators.

As an integrated and relative concept, SMEs' competitiveness in our understanding includes three interrelated aspects [Man et al., 2002]:

- internal and external development factors;

- success in accomplishing specific results;

- achievement of performance indicators.

An indicator of companies' competitiveness is their market stability, i.e., the ability to maintain or expand the scale of their operations over a relatively long period.

Two fundamental approaches can be distinguished in the strategic management literature, which link competitiveness primarily with analyzing its potential. The "resource" approach is focused on internal factors. It is assumed that competitive advantages are based on the efficient use of unique available resources, capabilities, and key competencies which allow the company to surpass its rivals [Wernerfelt, 1984; Prahalad, Hamel, 1990; Barney, 1991]. The level of competition between companies depends upon "market commonality", which occurs if companies operate on the same market, consider it vital to their business, and have comparable resources ("resource similarity") [Chen, 1996; Peteraf, Bergen, 2003].

Other researchers point to the importance of market or industry characteristics. Companies can gain significant competitive advantages if they operate in attractive business sectors [Porter, 1980, 1985]. These approaches complement each other and thus allow one to assess the potential for becoming competitive in a narrow market segment or across the entire industry [Hitt et al., 2016]. Competition cannot be homogeneous since there are always players who apply strong pressure on others, while other companies are not perceived as important rivals [Barnett, 1997]. Managers' perception of the competition plays a major role: it determines their reaction to, among other things, competitors' actions [Hambrick, Mason, 1984; Porac et al., 1989; Porac, Thomas, 1990; Cattani et al., 2017]. There is an established link between enterprises' performance and the entrepreneur's competencies, including their ability to assess the competitive environment and create organizational opportunities for realizing the company's potential [Man et al., 2008]. It is the manager's competencies that ensure the company's long-term competitiveness and sustainable performance. 
Another important factor is formal and informal network connections. Small enterprises more often use informal channels to obtain the information they need, including that about product development, competition, work organization, and communication with suppliers and customers [Kingsley, Malecki, 2004]. However, all of the above approaches are limited to identifying the link between no more than two aspects of competitiveness: the role of available resources and managers' competencies. Meanwhile actually becoming competitive in volves the complex interaction between at least two groups of internal factors, objective and subjective ones, including a set of specific variables. Based on this, [Lafuente et al., 2019] assessed companies' performance, depending on their size, using a competitiveness index based on 10 different factors: human capital, technology, strategic decisionmaking, product characteristics, marketing, use of ICT, networking, specific features of the domestic market, and internationalization. Making use of one's strengths and levelling weaknesses, is of particular importance for improving small enterprises' productivity. Since companies have to become competitive in different socioeconomic and legal environments, the overall context also should be considered. In transition countries, strategic decisions that affect companies' competitiveness are largely determined by the institutional environment [Puffer, McCarthy, 2011; Welter, 2011; Welter, Smallbone, 2011].

The international analysis presented in [Abel-Koch, Gerstenberger, 2014] ${ }^{1}$ showed that in Brazil, Russia, and China, SMEs' competitiveness is limited by institutional factors such as bureaucracy, corruption, political and social instability, and the lack of appropriate business development infrastructure. Under these circumstances, companies' competitive positions tend to be very different. The reasons for this variability can be traced using Russia as an example, where companies' operations very much depend upon informal institutions [May et al., 2000; Hitt et al., 2004; Puffer, McCarthy, 2011; Sauka, Chepurenko, 2017]. This also applies to other "transitional" countries where companies frequently rely on the support provided by external stakeholders as opposed to formal institutions, which, because of their poor development, do not appear to be sufficiently legitimate [Aidis et al., 2008; Chadee, Roxas, 2013; Volchek et al., 2013; Puffer et al., 2018].

A number of studies are devoted to Russian manufacturing enterprises' competitive strategies and the reasons for their adoption (see Table 1 for more). However, several gaps remain:
- the concept of "competitiveness" does not have a uniform, generally accepted definition;

- the relationship between competitive strategies and specific competitive factors has not been sufficiently explained;

- the impact of internal competitiveness aspects upon managers' perception of competitive pressure (as reflected in corporate strategies) does not seem to be clear;

- unique external factors affecting the availability of resources and the competitive strategy are not taken into account;

- the choice of particular strategies to match specific features of the market, in terms of major competitors' characteristics, has not been analyzed.

Russian SMEs' perception of their competitiveness may differ depending on the types of competitors they face, which affects their strategies. Russian players and their foreign and international competitors have incomparable resources [Chen, 1996; Peteraf, Bergen, 2003]. If a company competes exclusively with compatriots, the competition amounts to such aspects as the price-quality ratio, favorable terms of paying for services, and Russian brand recognition. To successfully compete with foreign manufacturers, innovations, focused customer relations, and the ability to identify and meet their preferences come to the fore [HSE, 2014]. However, these assumptions have not yet been empirically verified.

This paper proposes an original approach to defining the concept of "competitiveness". We study the mutual impact of resource availability and perceived level of competitive pressure as expressed in performance indicators (the company's sustainable development). In the case of SMEs, stakeholder groups other than managers play a very limited role in making key decisions. There are reasons to believe that it is the perception of the small firm's competitiveness by its managers that leads to optimizing the availability and use of resources, which is seen as a key factor in maintaining a strong competitive position. We examine how SMEs' internal competitiveness factors affect their managers' perception of competitive pressure in the Russian manufacturing industry. The analysis is carried out for two competitor types: compatriots and foreign manufacturers.

\section{The Conceptual Model and Study Hypotheses}

The conceptual structure of the study is presented in Figure 1, the hypotheses in Table 2. The paper considers five key factors which we believe define the competitive pressure on Russian manufacturing SMEs from domestic and foreign players:

1 This study covered the US, Germany, the UK, France, Japan, Brazil, Russia, China, Spain, and Italy. 
Table 1. Russian Manufacturing Companies' Competitive Strategies

\begin{tabular}{|l|l|}
\hline \multicolumn{1}{|c|}{ Strategy type } & \multicolumn{1}{c|}{ Content } \\
\hline Clingfish & $\begin{array}{l}\text { Establishing strong relationships with large partner companies allows small specialized firms which primarily } \\
\text { serve just a single (or a few) big clients located in the same region to avoid fierce competition. }\end{array}$ \\
\hline Copy-paste & $\begin{array}{l}\text { The enterprises' technological level is generally not high enough to develop their own technologies, so they are } \\
\text { forced to borrow them. }\end{array}$ \\
\hline No outsiders & $\begin{array}{l}\text { Many companies which do not use resources efficiently enough choose one of the following two strategies: } \\
\text { rely on domestic market niches inaccessible to third-party players to avoid a strong pressure from market } \\
\text { leaders; } \\
\text { enjoy state regulation protection, which limits the competition from stronger foreign players. }\end{array}$ \\
\hline
\end{tabular}

Note: the above strategy types are suggested by the authors.

Source: compiled by the authors based on [HSE, 2008, 2014; Gonchar, 2009; Alimova, 2017]

- technological level of products;

- use of ICT;

- strategic partnerships;

- external funding sources;

- product markets.

Enterprise size, age, and industry affiliation according to the taxonomy suggested by Keith Pavitt (Pavitt, 1984) were used as control variables. Note that competitiveness factors may vary for competitive pressure from Russian and foreign players.

\section{Technological Level of Products}

In this study, the technological level of the company's product is assessed in relation to products offered by its Russian and foreign competitors. Technological aspects of the company's strategy are crucial for its success in the competitive environment. They serve as a basis for drafting an action plan: a set of guidelines to efficiently use technological resources [Zahra, 1996]. Successful implementation of this plan depends on the adequate identification and management of human and social resources (such as knowledge, access to technology, work experience in large companies, etc.) [Garcia-Cabrera et al., 2019]. However, technological resources alone are not enough to ensure competitiveness. Strategic flexibility on external markets is also required, which will allow one to reach an acceptable technological level to be able to create an innovative product in the future [Kapasuwan et al., 2007]. A competitive advantage can be secured by acquiring technologies externally, if they can be applied to improve distribution and logistics in the supply chain [Knight, 2000]. Various strategies to improve the technological level, such as innovation and marketing differentiation, price reduction, and so on can significantly reduce competitive pressure on SMEs [Spanos, Lioukas, 2001].

The Russian manufacturing industry lags far behind the leading countries' because most enterprises lack the resources required for technological development [Gonchar, 2009; Kuznetsov et al.,
2011; HSE, 2014]. Therefore, it is assumed that companies offering products whose technological level is on a par with or exceeds the best Russian models do not experience significant competitive pressure (hypothesis $\mathrm{H} 1$ ).

\section{Use of Information and Communication Technology}

ICT, such as a websites, e-commerce, and customer relationship management (CRM) systems are considered important for maintaining competitive positions. The application of ICT can change the rules of competition in the industry, transform the company's operations, and create additional advantages [Porter, Millar, 1985]. ICT development strategies are applied if confrontation with other players threatens the firm's survival [Rivard et al., 2006]. Previously, SME managers' attention was mainly focused on production; however, due to changes in the market environment brought by the internet technologies, the priority shifted to identifying and meeting customers' needs by applying digital resources [Harrigan et al., 2011; Nguyen et al., 2015]. A systemic analysis of SMEs' marketing practices revealed that adapting ICTs for marketing purposes became a major driver of change and development [Bocconcelli et al., 2018]. Competition forces managers to use strategic resources to better understand customers and competitors through the effective use of marketing tools [O 'Cass, Weerawardena, 2010]. Digital technology facilitates interactions with customers and partners on the international market [Pergelova et al., 2019]. Having a foreign language website and using an e-commerce system is an important condition for Russian companies' entering foreign markets [Fedyunina, Averyanova, 2018]. Studies confirm there is a positive correlation between SMEs' export activities and their use of digital technology [Kuzyk et al., 2020]. We assume that the use of ICT provides a competitive advantage by reducing pressure from other manufacturers (hypothesis H2). 


\section{Figure 1. Conceptual Model of the Study}

SMEs' competitiveness factors
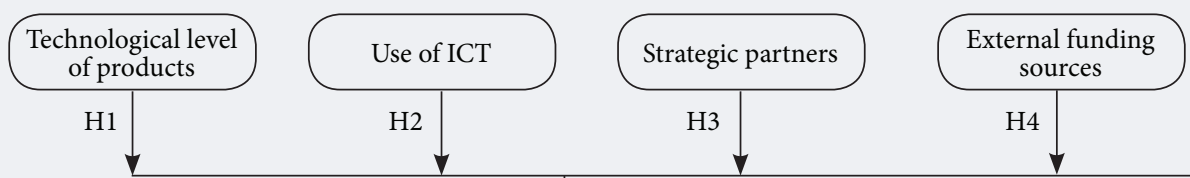

Product markets
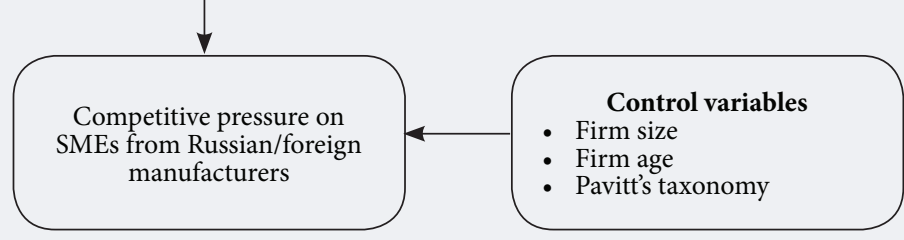

Source: compiled by the authors.

\section{Strategic Partners}

Strategic partnerships are understood as a set of network connections that can be used by managers and entrepreneurs to strengthen their companies' competitive positions [Jarillo, 1988]. Being a member of such networks provides numerous competitive advantages such as access to information, resources, markets, technologies, and so on. [Gulati et al., 2000]. Since SMEs tend to face serious resource constraints, problems with implementing innovations, and with internationalization, maintaining such partnerships is an important part of their development strategy in a competitive environment [Street, Cameron, 2007; Agostini, Nosella, 2019]. They acquire additional strategic resources including new formal and informal communication channels, access to R\&D results and new markets, which can help optimize the creation of added value [Partanen et al., 2018], [Kingsley, Malecki, 2004; Hernandez-Carrion et al., 2017; Martin et al., 2019].

In less developed markets, strategic partnerships can help deal with problems such as inadequate infrastructure and institutional constraints which hinder development [Mesquita, Lazzarini, 2008].
Chinese small and medium enterprises - members of technological alliances tend to perceive the competition they face as low [Wu, Pangarkar, 2010]. Surveys conducted in 2008 and 2010 revealed companies' increased involvement in innovative cooperation, presumably due to the latter's increased role in overcoming the effects of the economic crisis [Rebiazina et al., 2013].

Thus, cooperation expands SMEs' market opportunities, which would be harder to achieve on their own. It is assumed that entering into partnerships enterprises experience lower competitive pressure from other manufacturers (hypothesis H3).

\section{External Funding Sources}

By external funding we understand any sources other than the company's own funds. It is crucial for SMEs, especially after the financial crisis of 2008-2009 [OECD, 2017]. Small and medium companies need additional investments, primarily to accomplish the following objectives:

- focus on growth [McMahon, 2001];

- diversify by developing products with unique characteristics [Camisón, Villar-López, 2010];

\section{Table 2. Study Hypotheses}

\begin{tabular}{|l|l|}
\hline Hypothesis & \multicolumn{1}{|c|}{ Description } \\
\hline H1 & $\begin{array}{l}\text { If the technological level of the company's main product is on a par with, or exceeds the best Russian models, the company } \\
\text { managers perceive the competitive pressure from other manufacturers, including foreign ones, as low }\end{array}$ \\
\hline H2 & $\begin{array}{l}\text { Russian manufacturing SMEs that use ICT (websites, e-commerce, CRM systems) to promote their products experience } \\
\text { low competitive pressure from domestic and foreign manufacturers alike }\end{array}$ \\
\hline H3 & $\begin{array}{l}\text { Having strategic partners contributes to SME managers' perceiving the competitive pressure from Russian and foreign } \\
\text { manufacturers as low }\end{array}$ \\
\hline H4 & $\begin{array}{l}\text { If SME managers have access to external funding sources, they perceive competitive pressure from Russian and foreign } \\
\text { players as insignificant }\end{array}$ \\
\hline H5 & $\begin{array}{l}\text { SME managers are inclined to assess the competitive pressure from Russian manufacturers as low if their company operates } \\
\text { on the regional market, and the competitive pressure from foreigners as high if the company operates on the Russian } \\
\text { national, CIS, and global markets }\end{array}$ \\
\hline Source: compiled by the authors.
\end{tabular}


- improve their export performance [St-Pierre et al., 2018].

In the Russian context, SMEs' access to investments is limited to partners' and bank loans [Sokolov, Rudnik, 2014]. Studies show that manufacturing companies typically are not ready to put their business to risk and apply for bank loans, even if they are experiencing financial constraints. This is due to high interest rates and the generally insufficiently developed banking services market [Golikova, Kuznetsov, 2017; Alimova, 2017]. Therefore, it can be assumed that companies with access to reliable external funding sources have better development opportunities and experience lower competitive pressure (hypothesis $\mathrm{H} 4$ ).

\section{Product Markets}

We consider the full range of possible markets for SMEs, from local to global ones. Diversifying markets allows companies to gain a significant competitive advantage, change configuration and the value chain [Porter, 1985]. It has been established that the wider the market coverage, the more likely the company is to innovate [Radas, Božić, 2009]. A natural consequence of SMEs' growth is expanding the sales geography. Entering new markets leads to an increased number of customers, which in turn makes it possible to expand production $[\mathrm{Lu}$, Beamish, 2001]. Accessing information on foreign markets is much more difficult than at home, so to improve export performance, the competitive strategy of such enterprises should rely on exclusive information [Julien, Ramangalahy, 2003].

Manufacturing enterprises in Russia operate mainly at the local and regional levels. Low competition from other domestic manufacturers in this case is due to high entry barriers and/or the market's low appeal for stronger players [HSE, 2008; Alimova, 2017]. Only a few such companies operate in the CIS markets, where they face a larger number of rivals including foreign ones [HSE, 2014]. Thus, SMEs which sell mainly on specific Russian regional markets are likely to experience low competitive pressure from other Russian manufacturers. Meanwhile those doing business across Russia, in the CIS, and on global markets face fierce competition from foreign players. Hence hypothesis H5 (see Table 2).

\section{Methodology of the Study}

\section{The Sample}

Our analysis is based on a survey of 1,950 Russian manufacturing enterprises with more than $10 \mathrm{em}$ - ployees, conducted in the scope of the RuFIGE project (Russian Enterprises in the Global Economy). ${ }^{2}$ The survey was conducted by the GFK-Rus International Institute for Marketing and Social Research in 60 Russian regions during 2014 in the format of personal interviews with company managers. The questionnaire included questions which allowed the researcher to assess companies' competitiveness in the following aspects: organizational structure, personnel, innovation, investments, foreign trade, and business climate. The sample of the study is random, stratified, representative in terms of sectors and enterprise size, but its regional coverage is limited. To bring the sample into line with the structure of the general population of enterprises and stratify it by size groups and specific sectors, two additional variables were introduced into the RuFIGE database: relative and absolute weight. Each cell representing sectors and size groups has the same weight values, which eliminates distortions caused by the large number of firms in these categories.

For the purposes of our study, 1,677 Russian manufacturing SMEs with between 10 and 499 employees on the payroll were included in the sample. ${ }^{3}$ Out of them, $70 \%$ were small, and the rest were medium. In terms of economic activity, the companies were broken down into nine groups. The largest one (over $20 \%$ of the surveyed enterprises) was food industry (22.7\%), the smallest (4\%) included manufacturers of transport equipment. Three sectors (wood processing and pulp and paper industry; production of machinery and equipment; and metallurgy and production of metal products) were represented more or less equally at $12-13 \%$. The sample structure is presented in detail in Table 3.

\section{The Model and Variables Applied in the Study}

The binary logistic regression model [Hair et al., 2014] was used as the main tool for assessing the impact of competitiveness factors on Russian manufacturers' perception of competitive pressure (subsequently referred to as just "competitive pressure", for brevity):

$\mathrm{Y}$ (competitive pressure) $=\beta_{0} \beta_{1}$ Technology level of product ${ }_{i}+\beta_{2}$ Use of ICT IC $_{i}+\beta_{3}$ Strategic partners $_{i}+\beta_{4}$ External funding $_{i}+\beta_{5}$ Product markets $_{\mathrm{i}}+\beta_{6}$ Control variables $_{\mathrm{i}}+\varepsilon_{\mathrm{i}}$

Two models are considered. In the first one, competitive pressure from domestic manufacturers is the dependent variable, in the second one - competition from foreign players. Both these variables are binary. The competition indicator takes the value 0 (low competitive pressure) if the respondent indi-

\footnotetext{
${ }^{2}$ For more about this project see: https://iims.hse.ru/rusfirms (accessed on 03.03.2020). It was funded in the framework of the HSE Basic Research Programme and carried out by the HSE Institute for Industrial and Market Studies (supervised by B. Kuznetsov and A. Yakovlev).

3 Certain authors also include companies with up to 500 workers in the small and medium enterprises category [Shirokova et al., 2013; Volchek et al., 2013].
} 
Table 3. Sample Structure

\begin{tabular}{|c|c|c|c|}
\hline Criterion & Group & Number & $\begin{array}{c}\text { Total } \\
(\%)\end{array}$ \\
\hline \multirow{2}{*}{$\begin{array}{l}\text { Year of } \\
\text { establishment* }\end{array}$} & 1988 or earlier & 267 & 16.3 \\
\hline & 1989-2013 & 1403 & 83.7 \\
\hline \multirow{5}{*}{$\begin{array}{l}\text { Enterprise size } \\
\text { (number of } \\
\text { employees) }\end{array}$} & $10-19$ & 344 & 20.5 \\
\hline & $20-49$ & 503 & 30 \\
\hline & $50-100$ & 334 & 19.9 \\
\hline & $101-249$ & 325 & 19.4 \\
\hline & $250-499$ & 171 & 10.2 \\
\hline \multirow{9}{*}{ Sector } & Food production & 380 & 22.7 \\
\hline & $\begin{array}{l}\text { Textile, sewing, leather } \\
\text { and shoe production }\end{array}$ & 161 & 9.6 \\
\hline & $\begin{array}{l}\text { Wood processing, } \\
\text { production of wood } \\
\text { products, pulp and paper }\end{array}$ & 215 & 12.8 \\
\hline & $\begin{array}{l}\text { Chemical industry, } \\
\text { production of coke and } \\
\text { petroleum products, } \\
\text { rubber and plastic } \\
\text { products }\end{array}$ & 180 & 10.7 \\
\hline & $\begin{array}{l}\text { Production of other non- } \\
\text { metallic products }\end{array}$ & 141 & 8.4 \\
\hline & $\begin{array}{l}\text { Metallurgy, and } \\
\text { production of metal } \\
\text { products }\end{array}$ & 202 & 12 \\
\hline & $\begin{array}{l}\text { Production of machinery } \\
\text { and equipment }\end{array}$ & 212 & 12.6 \\
\hline & $\begin{array}{l}\text { Production of electrical, } \\
\text { electronic and optical } \\
\text { equipment }\end{array}$ & 119 & 7.1 \\
\hline & $\begin{array}{l}\text { Vehicles and transport } \\
\text { equipment }\end{array}$ & 67 & 4 \\
\hline \multicolumn{4}{|c|}{$\begin{array}{l}\text { Note: }:^{*} \text { including missing values. } \\
\text { Source: compiled by the authors. }\end{array}$} \\
\hline
\end{tabular}

cated that there was no competition from domestic or foreign manufacturers, or it was insignificant. If it was reported that competition significantly or strongly affected the company, the indicator takes the value 1 (high competitive pressure). The variable "competitive pressure from foreign manufacturers" comprises two indicators: "competition from foreign manufacturers producing in Russia" and "competition from foreign manufacturers importing products into Russia". The preliminary statistical analysis revealed that $82 \%$ of the respondents experiencing strong competitive pressure from foreign companies producing in Russia also assessed competition from foreign manufacturers importing their products into the country as high. Accordingly, it was assumed that all foreign players make a single competitor group [HSE, 2014, p. 49].

Factors such as technological level of products, use of ICT (websites, e-commerce and CRM systems), strategic partnerships, external funding sources, and product markets (regional, national, the CIS, and international ones) were applied as independent variables. All independent variables are binary: they take the values 0 if the respondent answered the question about the presence of one of the above factors negatively, and the value 1 if the answer was positive.

The regression model also comprises a number of control variables: company age (the natural logarithm of the year it was established), company size (dummy variables of the number of employees), and industry affiliation according to Pavitt's taxonomy [Pavitt, 1984]. The following industry groups were used: "scale-efficient", conventional, specialized, and high-tech. The operationalization of the analyzed variables is presented in Table 4, the correlation matrix - in Table 5. All independent variables have low and moderate (mainly at the level of $\mathrm{p}<0.05)$ correlation with each other. The highest correlation coefficients were noted for the variables "scale-efficient industries" and "conventional industries" $(-0.568)$ at $5 \%$. Thus, it can be sufficiently confidently assumed there is no multicollinearity among the independent/control variables.

\section{Analysis and Results}

Table 6 presents descriptive statistics of the variables applied in the study. On average, slightly more than half of the enterprises (58\%) sell products whose technological level is on a par with or exceeds the best domestic models. As for the use of ICT, $80 \%$ of the firms have a website, $28 \%$ take part in e-commerce via the internet, while only $16 \%$ use CRM systems. A total of $49 \%$ of Russian SMEs are involved in strategic partnerships and $40 \%$ have access to external funding sources. Russian SMEs mainly sell on domestic markets, regional (79\%) and national (64\%) ones. A relatively small number of SMEs operate on foreign markets, including the CIS (20\%) and worldwide (6\%). For most variables, differences in the perception of competitive pressure from domestic and foreign manufacturers was discovered, so these groups were considered separately. A negligible proportion of companies in the sample reported they had no competition from either domestic $(0.5 \%)$ or foreign $(1.7 \%)$ manufacturers. The coefficient values presented in Table 7 indicate that both models are reliable and suitable for further analysis.

The presented results allow one to identify two groups of SMEs based on the factors affecting managers' perception of competition from domestic producers. The respondents who do have strategic partners and access to external funding, and operate on regional markets are highly likely to describe competitive pressure from compatriots as tangible. On the contrary, it is assessed as low if the company sells products of a high technological 


\section{Table 4. Operationalization of Variables}

\begin{tabular}{|c|c|}
\hline $\begin{array}{l}\text { Variables' } \\
\text { codes }\end{array}$ & Description and values of variables \\
\hline \multicolumn{2}{|r|}{ Dependent variables } \\
\hline B7_SME & Impact of competition from domestic manufacturers on enterprises' activities $(0=$ low; $1=$ high $)$ \\
\hline B89_SME & $\begin{array}{l}\text { Impact of competition from foreign manufacturers (producing in Russia, and/or importing their products) on enterprises' } \\
\text { activities ( } 0=\text { low; } 1=\text { high) }\end{array}$ \\
\hline \multicolumn{2}{|r|}{ Independent variables } \\
\hline B54_SME & $\begin{array}{l}\text { Enterprises' assessment of their main product's technological level }(0=\text { does not match best domestic, average foreign, } \\
\text { and best foreign models, } 1=\text { does match) }\end{array}$ \\
\hline B13_SME_23 & Company has a website $(0=$ no, $1=$ yes $)$ \\
\hline B13_SME_4 & Company participates in e-commerce (sells/buys via the internet) $(0=$ no, $1=$ yes $)$ \\
\hline B13_SME_5 & Company uses a customer relationship management system $(\mathrm{CRM})(0=$ no, $1=$ yes $)$ \\
\hline B36_SME & Company has strategic partners in Russia and abroad $(0=$ no, $1=$ yes $)$ \\
\hline B89_SME & Company had access to external funding sources in 2011-2013 (i.e. all sources other than own funds) $(0=$ no, $1=$ yes) \\
\hline B6_SME_1 & Company sells products on the regional market $(0=$ no, $1=$ yes $)$ \\
\hline B6_SME_2 & Company sells products on the Russian national market $(0=$ no, $1=$ yes $)$ \\
\hline B6_SME_3 & Company sells products on the CIS markets $(0=$ no, $1=$ yes $)$ \\
\hline B6_SME_4 & Company sells products on the global market $(0=$ no, $1=$ yes $)$ \\
\hline \multicolumn{2}{|r|}{ Control variables } \\
\hline F14_SME_1 & Company has $10-19$ employees $(0=$ no, $1=$ yes $)$ \\
\hline F14_SME_2 & Company has 20-49 employees $(0=$ no, $1=$ yes $)$ \\
\hline F14_SME_3 & Company has 50-100 employees $(0=$ no, $1=$ yes $)$ \\
\hline F14_SME_4 & Company has 101-249 employees $(0=$ no, $1=$ yes $)$ \\
\hline F14_SME_5 & Company has $250-499$ employees $(0=$ no, $1=$ yes $)$ \\
\hline B1_SME & Logarithm of the year company was established \\
\hline S1_SME_1 & Company operates in a "scale-efficient" industry $(0=$ no, $1=$ yes $)$ \\
\hline S1_SME_2 & Company operates in a conventional industry $(0=$ no, $1=$ yes $)$ \\
\hline S1_SME_3 & Company operates in a specialized industry $(0=$ no, $1=$ yes $)$ \\
\hline S1_SME_4 & Company operates in a high-technology industry $(0=$ no, $1=$ yes $)$ \\
\hline
\end{tabular}

level, uses a CRM system, and sells products on the global market.

As to competition from foreign players, if Russian SMEs offer products of a high technological level, use CRM systems, sell on regional and national markets, are involved in strategic partnerships, and have a medium size, the respondents tend to assess such competitive pressure as high. The exception is "scale-efficient" industries where it is perceived as low.

\section{Discussion of Results}

The empirical analysis confirmed some of the hypotheses fully and others partially. Hypothesis $\mathrm{H} 1$ turned out to be valid only for Model 1. Managers of enterprises which offer products of a high technological level assess the competitive pressure from domestic manufacturers as low and from foreign ones as high. Thus, being able to manufacture high-tech products makes only the SMEs that compete mainly with compatriots competitive, but not with foreign players. This is probably due to the fact that most of Russian manufacturing com- panies lag behind foreign competitors in terms of technological development [HSE, 2014].

Hypothesis $\mathrm{H} 2$ turned out to be valid only for the "CRM system" variable in Model 1. Companies which used such a system assessed competitive pressure from Russian manufacturers as low, and that from foreign ones as high. In other words, owning a CRM system allows a firm to maintain a position only on the domestic market and then only in the absence of pressure from foreign players. This is consistent with certain studies' findings about a positive correlation between SMEs' export activities and the application of digital technologies [Kuzyk et al., 2020].

The hypothesis testing the strategic partnership factor (H3) has not been confirmed in both models. Managers of companies involved in strategic partnerships reported high competitive pressure from both domestic and foreign manufacturers. Despite the various advantages cooperation in the innovation sphere provides [Gurkov, 2013; Rebiazina et al., 2013], our results indicate it does not affect Russian SMEs' competitiveness, regardless of the type of competition they encounter. 
Table 5. Correlation Matrix

\begin{tabular}{|c|c|c|c|c|c|c|c|c|c|c|c|}
\hline No. & Variables & 1 & 2 & 3 & 4 & 5 & 6 & 7 & 8 & 9 & 10 \\
\hline 1 & B54_SME & 1 & & & & & & & & & \\
\hline 2 & B13_SME_23 & $0.056^{*}$ & 1 & & & & & & & & \\
\hline 3 & B13_SME_4 & $0.075^{\star \star}$ & 0.009 & 1 & & & & & & & \\
\hline 4 & B13_SME_5 & $0.111^{\star *}$ & $0.069^{* *}$ & $0.269^{\star *}$ & 1 & & & & & & \\
\hline 5 & B36_SME & $0.137^{\star \star}$ & $0.123^{\star *}$ & $0.078^{\star \star}$ & $0.108^{\star *}$ & 1 & & & & & \\
\hline 6 & B89_SME & $0.072^{\star *}$ & $0.062^{*}$ & 0.034 & $0.072^{* *}$ & $0.094^{* *}$ & 1 & & & & \\
\hline 7 & B6_SME_1 & $-0.061^{\star}$ & -0.011 & -0.022 & 0.023 & -0.020 & $0.051^{*}$ & 1 & & & \\
\hline 8 & B6_SME_2 & $0.197^{\star *}$ & $0.139^{\star *}$ & $0.093^{\star *}$ & $0.060^{*}$ & $0.160^{* *}$ & $0.068^{\star *}$ & $-0.299^{\star *}$ & 1 & & \\
\hline 9 & B6_SME_3 & $0.196^{* *}$ & $0.129^{* *}$ & $0.105^{\star *}$ & $0.155^{\star *}$ & $0.130^{* *}$ & 0.036 & $-0.094^{\star *}$ & $0.316^{\star *}$ & 1 & \\
\hline 10 & B6_SME_4 & $0.119^{* *}$ & $0.067^{\star \star}$ & $0.095^{\star \star}$ & $0.098^{\star \star}$ & $0.117^{\star \star}$ & 0.014 & $-0.059^{\star}$ & $0.110^{\star \star}$ & $0.342^{\star \star}$ & 1 \\
\hline 11 & F14_SME_1 & $-0.090^{* *}$ & $-0.052^{*}$ & $-0.087^{\star *}$ & $-0.129^{\star *}$ & $-0.136^{* *}$ & $-0.052^{*}$ & $0.097^{\star *}$ & $-0.135^{\star *}$ & $-0.140^{* *}$ & $-0.083^{* *}$ \\
\hline 12 & F14_SME_2 & -0.047 & $-0.071^{\star *}$ & -0.017 & $-0.077^{* *}$ & $-0.066^{\star *}$ & $-0.068^{\star *}$ & 0.030 & $-0.053^{*}$ & $-0.085^{\star *}$ & $-0.072^{\star \star}$ \\
\hline 13 & F14_SME_3 & 0.012 & -0.034 & 0.028 & -0.009 & -0.016 & -0.036 & -0.028 & 0.008 & $-0.055^{\star}$ & -0.009 \\
\hline 14 & F14_SME_4 & $0.089^{\star *}$ & $0.122^{\star *}$ & 0.043 & $0.138^{* *}$ & $0.129^{* *}$ & $0.118^{\star *}$ & $-0.106^{\star *}$ & $0.117^{\star \star}$ & $0.182^{\star *}$ & $0.081^{\star *}$ \\
\hline 15 & F14_SME_5 & $0.057^{*}$ & $0.063^{* *}$ & $0.049^{*}$ & $0.121^{\star *}$ & $0.137^{\star *}$ & $0.066^{* *}$ & 0.000 & $0.097^{\star \star}$ & $0.150^{* *}$ & $0.127^{\star *}$ \\
\hline 16 & B1_SME & -0.029 & $0.125^{\star *}$ & 0.011 & 0.016 & $0.101^{\star *}$ & 0.035 & -0.025 & $0.069^{* *}$ & $0.123^{* *}$ & $0.101^{* *}$ \\
\hline 17 & S1_SME_1 & -0.044 & -0.008 & 0.007 & 0.020 & 0.020 & 0.030 & $0.069^{\star \star}$ & $-0.122^{* *}$ & -0.047 & -0.013 \\
\hline 18 & S1_SME_2 & $-0.064^{* *}$ & $-0.062^{*}$ & -0.042 & $-0.071^{\star *}$ & $-0.123^{\star *}$ & -0.031 & -0.002 & 0.017 & $-0.095^{\star *}$ & -0.040 \\
\hline 19 & S1_SME_3 & $0.083^{\star *}$ & 0.032 & 0.044 & 0.044 & $0.064^{* *}$ & 0.001 & $-0.062^{*}$ & $0.070^{\star *}$ & $0.072^{\star \star}$ & 0.024 \\
\hline 20 & S1_SME_4 & $0.066^{\star *}$ & $0.065^{\star *}$ & -0.007 & 0.012 & $0.063^{* *}$ & -0.008 & -0.038 & $0.100^{\star *}$ & $0.131^{\star *}$ & $0.051^{*}$ \\
\hline
\end{tabular}

\begin{tabular}{|c|c|c|c|c|c|c|c|c|c|c|c|}
\hline No. & Variables & 11 & 12 & 13 & 14 & 15 & 16 & 17 & 18 & 19 & 20 \\
\hline 11 & F14_SME_1 & 1 & & & & & & & & & \\
\hline 12 & F14_SME_2 & $-0.333^{\star *}$ & 1 & & & & & & & & \\
\hline 13 & F14_SME_3 & $-0.253^{\star \star}$ & $-0.326^{\star *}$ & 1 & & & & & & & \\
\hline 14 & F14_SME_4 & $-0.249^{* \star}$ & $-0.321^{\star \star}$ & $-0.245^{\star \star}$ & 1 & & & & & & \\
\hline 15 & F14_SME_5 & $-0.171^{\star \star}$ & $-0.221^{* *}$ & $-0.168^{\star \star}$ & $-0.165^{\star *}$ & 1 & & & & & \\
\hline 16 & B1_SME & $-0.176^{\star \star}$ & $-0.133^{\star *}$ & -0.022 & $0.140^{* *}$ & $0.283^{\star *}$ & 1 & & & & \\
\hline 17 & S1_SME_1 & $-0.057^{\star}$ & -0.027 & -0.001 & 0.036 & $0.072^{\star *}$ & 0.015 & 1 & & & \\
\hline 18 & S1_SME_2 & $0.066^{\star *}$ & $0.071^{\star \star}$ & 0.019 & $-0.118^{\star *}$ & $-0.066^{\star *}$ & $-0.057^{*}$ & $-0.568^{\star *}$ & 1 & & \\
\hline 19 & S1_SME_3 & -0.021 & -0.028 & 0.026 & $0.050^{*}$ & -0.030 & 0.044 & $-0.466^{* *}$ & $-0.238^{\star *}$ & 1 & \\
\hline 20 & S1_SME_4 & 0.030 & -0.021 & $-0.061^{*}$ & 0.046 & 0.012 & 0.000 & $-0.322^{\star *}$ & $-0.164^{\star *}$ & $-0.135^{\star *}$ & 1 \\
\hline
\end{tabular}

Note: ${ }^{* *} \mathrm{p}<0.05,{ }^{*} \mathrm{p}<0.1$

Source: compiled by the authors.

The study did not confirm the $\mathrm{H} 4$ hypothesis either. It was established that even with access to external funding, managers considered competition from compatriots as tangible, while regarding competition with foreign players this factor did not play a role. Foreign investments are traditionally seen as an essential condition for SMEs' success (see, e.g., [Golikova, Kuznetsov, 2017]). Our results show, however, that their effect is actually limited: other factors are important for successfully competing with compatriots, and in the case of foreigners, this aspect alone is not sufficient.

Hypothesis $\mathrm{H} 5$ was partially confirmed. Managers of enterprises operating on regional markets only assess competitive pressure from domestic manufacturers as high, and from foreign ones as low. These results disagree with the thesis that Russian firms face low competition from compatriots on local or regional markets [HSE, 2008, 2014]. However, upon entering the Russian national market the perception changes: competitive pressure from foreign manufacturers is assessed as high. In addition, companies which operate on the global market describe competition from Russian firms as low. This confirms the well-known fact about the low representation of Russian manufacturers in international marketplaces.

Finally, SME managers perceive competitive pressure from foreign players as high if their enterprises are medium in size (employ between 101-249 people). Apparently, the larger the company, the less often it competes with small, local actors, and the more often with large and international ones.

The second significant control variable shows that SME managers in "scale-efficient" industries face low competitive pressure from foreign manufac- 
Table 6. Descriptive Statistics

\begin{tabular}{|c|c|c|c|c|c|c|}
\hline \multirow{3}{*}{ Variable } & \multicolumn{6}{|c|}{ Source of competitive pressure } \\
\hline & \multicolumn{3}{|c|}{ Russian manufacturers } & \multicolumn{3}{|c|}{ Foreign manufacturers } \\
\hline & Low & High & Total & Low & High & Total \\
\hline Technological level of products (\%) & 62.7 & 55.3 & 58.0 & 54.5 & 64.8 & 58.3 \\
\hline Website (\%) & 79.0 & 81.0 & 80.2 & 79.0 & 83.1 & 80.5 \\
\hline e-Commerce (\%) & 29.0 & 27.5 & 28.0 & 28.5 & 28.1 & 28.3 \\
\hline CRM systems (\%) & 17.1 & 14.8 & 15.6 & 14.1 & 18.7 & 15.8 \\
\hline Strategic partners (\%) & 44.2 & 52.4 & 49.4 & 45.3 & 56.6 & 49.5 \\
\hline External funding (\%) & 34.3 & 43.1 & 39.9 & 38.2 & 42.8 & 39.9 \\
\hline Product markets (regional) (\%) & 75.9 & 81.8 & 79.6 & 79.4 & 80.1 & 79.7 \\
\hline Product markets (national) (\%) & 66.4 & 62.4 & 63.9 & 59.0 & 72.1 & 63.9 \\
\hline Product markets (CIS) (\%) & 19.1 & 19.9 & 19.6 & 16.9 & 24.5 & 19.7 \\
\hline Product markets (global) (\%) & 7.3 & 4.4 & 5.5 & 4.8 & 6.7 & 5.5 \\
\hline Number of employees 10-19 (\%) & 19.4 & 21.1 & 20.5 & 21.5 & 18.6 & 20.4 \\
\hline Number of employees 20-49 (\%) & 31.7 & 29.1 & 30.0 & 31.1 & 28.4 & 30.1 \\
\hline Number of employees 50-100 (\%) & 22.4 & 18.4 & 19.8 & 20.7 & 18.6 & 19.9 \\
\hline Number of employees 101-249 (\%) & 17.5 & 20.7 & 19.5 & 16.7 & 23.8 & 19.4 \\
\hline Number of employees 250-499 (\%) & 9.1 & 10.8 & 10.2 & 10.0 & 10.7 & 10.3 \\
\hline Company age & $21.1(26.0)$ & $19.5(21.5)$ & $19.6(21.9)$ & $20.1(21.8)$ & $19.3(20.5)$ & 19.6(21.7) \\
\hline “Scale-efficient" industry (\%) & 51.5 & 53.3 & 52.6 & 56.7 & 46.2 & 52.8 \\
\hline Conventional industry (\%) & 24.6 & 21.3 & 22.5 & 21.9 & 23.6 & 22.6 \\
\hline Specialized industry (\%) & 15.1 & 17.1 & 16.4 & 14.5 & 18.8 & 16.1 \\
\hline High-tech industry (\%) & 8.9 & 8.3 & 8.5 & 6.9 & 11.4 & 8.5 \\
\hline Number of observations & 613 & 1056 & 1669 & 1040 & 609 & 1649 \\
\hline $\begin{array}{l}\text { Note: standard error in brackets. } \\
\text { Source: compiled by the authors. }\end{array}$ & & & & & & \\
\hline
\end{tabular}

turers. These are mostly companies which make durable goods: machines, metallurgical and metal products, vehicles, and electronic and optical equipment (see Table 3). In these sectors (which are largely oriented towards public orders) there are high barriers in place, limiting the competition from more competitive foreign manufacturers.

\section{Conclusions and Recommendations}

This study makes a contribution to the existing literature [HSE, 2008, 2014; Alimova, 2017]. The perception of competition by manufacturing SME managers was analyzed taking into account a number of factors: technological level of products, the use of ICT, strategic partnerships, access to external funding, and product markets. It was found that high technological level, the application of CRM systems, and external investments alone are not enough for Russian manufacturing SMEs to maintain sustainable positions on the global market. Apart from improving technologies and implementing innovations, additional support is required to succeed on international markets in particular enhancing Russian SMEs' competencies in such areas as branding, customization, international product certification, and so on. Companies' strategies and prospects can be improved by public policies, including the provision of expert services to promising SMEs by specialized business promotion agencies. The state should ensure the appropriate quality of such services [OECD, 2015]. Examples include assisting in export and exhibition activities, covering some of the costs of obtaining international product and technology quality certificates, and other mechanisms described in detail in international literature [Lu, Beamish, 2001; Julien, Ramangalahy, 2003]. In the case of Russian SMEs, which mainly compete with their compatriots, neither technological level, availability of CRM systems, nor external funding sources have an impact upon their success rate. Other aspects and factors work here (possibly interpersonal ones, etc.). This means that the naturally prevailing level of competition from domestic producers does not provide a strong incentive for Russian SMEs to step up product and process innovation. A vicious circle has emerged, breaking which will help expand the range of opportunities for third-party players to enter the market.

The importance of providing public organizational support to manufacturing SMEs to help them build partnerships and integrate into technological chains (a set of measures collectively referred to as 
Table 7. Logistic Regression Models for Analyzing SMEs' Competitiveness Factors and Competitive Pressure from Manufacturers

\begin{tabular}{|c|c|c|}
\hline \multirow{2}{*}{ Variable } & \multicolumn{2}{|c|}{$\begin{array}{c}\text { Dependent variable: competitive } \\
\text { pressure on SMEs from } \\
\text { manufacturers }\end{array}$} \\
\hline & $\begin{array}{l}\text { Domestic } \\
\text { manufacturers } \\
(\text { Model 1) }\end{array}$ & $\begin{array}{c}\text { Foreign } \\
\text { manufacturers } \\
(\text { Model 2) }\end{array}$ \\
\hline Constant & $0.444(0.401)$ & $-1.391^{\star * *}(0.406)$ \\
\hline $\begin{array}{l}\text { Technological level of } \\
\text { products }\end{array}$ & $-0.323^{* * *}(0.117)$ & $0.274^{\star *}(0.118)$ \\
\hline Website & $0.196(0.141)$ & $0.087(0.149)$ \\
\hline e-Commerce & $0.010(0.126)$ & $-0.173(0.127)$ \\
\hline CRM systems & $-0.280^{*}(0.157)$ & $0.301^{*}(0.157)$ \\
\hline Strategic partners & $0.305^{\star * \star}(0.115)$ & $0.294^{\star \star}(0.115)$ \\
\hline External funding & $0.344^{* * *}(0.114)$ & $0.074(0.114)$ \\
\hline $\begin{array}{l}\text { Product markets } \\
\text { (regional) }\end{array}$ & $0.326^{\star *}(0.142)$ & $0.272^{\star}(0.145)$ \\
\hline $\begin{array}{l}\text { Product markets } \\
\text { (national) }\end{array}$ & $-0.124(0.130)$ & $0.464^{\star \star \star}(0.132)$ \\
\hline Product markets (CIS) & $0.160(0.161)$ & $0.114(0.157)$ \\
\hline Product markets (global) & $-0.646^{\star \star}(0.251)$ & $0.115(0.253)$ \\
\hline \multicolumn{3}{|c|}{ Control variables } \\
\hline $\begin{array}{l}\text { Company size } \\
\text { (10-19 employees) }\end{array}$ & $-0.146(0.237)$ & $0.170(0.236)$ \\
\hline $\begin{array}{l}\text { Company size } \\
\text { (20-49 employees) }\end{array}$ & $-0.276(0.219)$ & $0.114(0.218)$ \\
\hline $\begin{array}{l}\text { Company size } \\
\text { (50-100 employees) }\end{array}$ & $-0.331(0.225)$ & $0.016(0.226)$ \\
\hline $\begin{array}{l}\text { Company size } \\
\text { (101-249 employees) }\end{array}$ & $0.066(0.222)$ & $0.403^{\star}(0.216)$ \\
\hline Company age & $-0.049(0.066)$ & $0.032(0.066)$ \\
\hline "Scale-efficient" industry & $-0.003(0.202)$ & $-0.532^{\star * *}(0.198)$ \\
\hline Conventional industry & $-0.004(0.221)$ & $-0.145(0.217)$ \\
\hline Specialized industry & $0.223(0.231)$ & $-0.162(0.224)$ \\
\hline \multicolumn{3}{|c|}{ Model coefficients } \\
\hline Log likelihood & 1929.753 & 1896.051 \\
\hline $\begin{array}{l}\text { Likelihood ratio test } \chi^{2} \\
\text { (p-value) }\end{array}$ & $\begin{array}{l}54.434 \\
(0.000) \\
\end{array}$ & $\begin{array}{l}81.188 \\
(0.000) \\
\end{array}$ \\
\hline Pseudo $\mathrm{R}^{2}$ & 0.048 & 0.072 \\
\hline Number of observations & 1514 & 1497 \\
\hline
\end{tabular}

"bridging") [Amezcua et al., 2013] has been noted in international literature. Enterprises can achieve a sustainable competitive advantage in the industry if the state actively promotes their integration into global value chains [Lazzarini, 2015]. Having strategic partners does not lead to Russian SME managers' perceiving the competition they face as low, regardless of whether they compete with Russian or foreign manufacturers. Therefore, stepping up industrial contracting and establishing strategic collaborations with larger partners alone will not increase manufacturing SMEs' sustainability.
Different "weight classes" have emerged among Russian small and medium-sized companies. The ones which operate only on local markets are not as susceptible to competition from large foreign companies and consider other Russian companies to be their main rivals. However, those that entered the Russian national market do feel high competitive pressure from foreigners. Stepping up their operations and entering the all-Russian market takes SMEs outside their "comfort zone", prompting them to adopt more advanced production, management, and logistics technologies. The data on mediumsized companies is noteworthy in this respect, which are interregional players by definition. By eliminating the barriers hindering business scaling (many of which are well-described in the literature) [Simachev et al., 2016; Simachev, Kuzyk, 2017], the state could help strengthen the competitiveness and sustainability of Russian manufacturing SMEs. Finally, a very small group of players operating on the global market stands out, who do not feel any pressure from compatriots at all. Promoting exports of their products and services fully relies on participating in relevant alliances and business associations, with public support.

This study has certain limitations. First of all, the data available for analysis did not allow for reliably identifying leaders and outsiders among the surveyed SMEs in terms of objective financial and economic performance indicators (turnover growth, revenues, etc.). Meanwhile, this would help to find out exactly how specific internal factors affect small and medium companies at different levels of development [Kuzyk et al., 2020]. The paper examined SMEs' competitiveness factors which determine high and low competitive pressure from domestic and foreign players. It should be noted that a different approach is possible: to examine how competitive pressure promotes or hinders companies' activities, since the impact of potential competitive factors on competitive pressure is bilateral [Wu, Pangarkar, 2010]. Therefore, other factors affecting competitive pressure from manufacturers can also be studied. Plus, only Russian small and medium-sized manufacturing enterprises were analyzed, which suggests the possibility of checking and comparing the results by examining other sectors of the Russian economy. Finally, for research purposes, competitive pressure can be also seen as a mediator, i.e. when studying, for example, the impact of the institutional environment upon various kinds of investments made to obtain a competitive advantage in export activities, in situations of different pressures from domestic and foreign manufacturers [Ngo, Janssen, 2016]. 


\section{References}

Abel-Koch J., Gerstenberger J. (2014) KfW Competitiveness Indicator 2014, Frankfurt am Main: KfW. Available at: https://www.kfw.de/PDF/Download-Center/Konzernthemen/Research/PDF-Dokumente-Wettbewerbsindikator/ Wettbewerbsinsikator-2014_EN.pdf, accessed 19.05.2020.

Agostini L., Nosella A. (2019) Inter-organizational relationships involving SMEs: A bibliographic investigation into the state of the art. Long Range Planning, vol. 52, pp. 1-31.

Aidis R., Estrin S., Mickiewicz T. (2008) Institutions and entrepreneurship development in Russia: A comparative perspective. Journal of Business Venturing, vol. 23, no 6, pp. 656-672.

Alimova T. (2017) The Impact of Competition on the Economic Behavior and Performance of Manufacturing SMEs in Russia. Entrepreneurship in Transition Economies: Diversity, Trends, and Perspectives (eds. A. Sauka, A. Chepurenko), Heidelberg; New York; Dordrecht; London: Springer, pp. 367-380.

Amezcua A.S., Grimes M.G., Bradley S.W., Wiklund J. (2013) Organizational sponsorship and founding environments: A contingency view on the survival of business-incubated firms, 1994-2007. Academy of Management Journal, vol. 56, no 6, pp. 1628-1654.

Barnett W.P. (1997) The dynamics of competitive intensity. Administrative Science Quarterly, vol. 42, no 1, pp. 128-160.

Barney J. (1991) Firm Resources and Sustained Competitive Advantage. Journal of Management, vol. 17, no 1, pp. 99-120.

Bocconcelli R., Cioppi M., Fortezza F., Francioni B., Pagano A., Savelli E., Splendiani S. (2018) SMEs and marketing: A systematic literature review. International Journal of Management Reviews, vol. 20, no 2, pp. 227-254.

Caloghirou Y., Protogerou A., Spanos Y., Papagiannakis L. (2004) Industry- versus Firm specific effects on performance: Contrasting SMEs and Large-sized firms. European Management Journal, vol. 22, no 2, pp. 231-243.

Camisón C., Villar-López A. (2010) Effect of SMEs` international experience on foreign intensity and economic performance: The mediating role of internationally exploitable assets and competitive strategy. Journal of Small Business Management, vol. 48, no 2, pp. 116-151.

Cattani G., Porac J.F., Thomas H. (2017) Categories and competition. Strategic Management Journal, vol. 38, no 1, pp. 64-92.

Chadee D., Roxas B. (2013) Institutional environment, innovation capacity and firm performance in Russia. Critical Perspectives on International Business, vol. 9, no 1/2, pp. 19-39.

Chen M-J. (1996) Competitor analysis and interfirm rivalry: Toward a theoretical integration. The Academy of Management Review, vol. 21, no 1, pp. 100-134.

Díaz-Chao Á., Sainz-González J., Torrent-Sellens J. (2016) The competitiveness of small network firm: A practical tool. Journal of Business Research, vol. 69, no 5, pp. 1769-1774.

Fedyunina A., Averyanova Yu. (2018) Empiricheskij analiz faktorov konkurentosposobnosti rossijskikh eksporterov v obrabatyvayushchikh otraslyakh [Empirical Analysis of Competitiveness Factors of Russian Exporters in Manufacturing Industries]. Ekonomicheskaya politika [Economic Policy], vol. 13, no 6, pp. 102-121 (in Russian).

Furrer O., Thomas H., Goussevskaia A. (2008) The structure and evolution of the strategic management field: a content analysis of 26 years of strategic management research. International Journal of Management Reviews, vol. 10, no 1, pp. 1-23.

Garcia-Cabrera A.M., Garcia-Soto M.G., Olivares-Mesa A. (2019) Entrepreneurs` resources, technology strategy, and new technology-based firms` performance. Journal of Small Business Management, vol. 57, no 4, pp. 1506-1530.

Golikova V., Kuznetsov B. (2017) Suboptimal Size: Factors Preventing the Growth of Russian Small and Medium-Sized Enterprises. Foresight and STI Governance, vol. 11, no 3, pp. 83-93.

Gonchar K. (2009) Innovatsionnoe povedenie promyshlennosti: razrabatyvat' nel'zya zaimstvovat' [Industry Innovations: Development versus Adaptation]. Voprosy Ekonomiki, no 12, pp.1-17 (in Russian).

Gulati R., Nohria N., Zaheer A. (2000) Strategic networks. Strategic Management Journal, vol. 21, no 3, pp. 203-215.

Gurkov I. (2013) Why some Russian industrial companies innovate regularly: Determinants of firms` decisions to innovate and associated routines. Journal for East European Management Studies, vol. 18, no 1, pp. 66-96.

Gurkov I., Avraamova E., Tubalov V. (2005) Konkurentosposobnost' i innovatsionnost' rossiiskikh promyshlennykh predpriyatii (po rezul'tatam massovogo oprosa ikh rukovoditelei) [Competitiveness and Innovativeness of Russian Industrial Enterprises (on the Results of a Large-scale Survey of Enterprises)]. Voprosy Ekonomiki, no 2, pp. 75-90.

Hair J.F., Black W.C., Babin B.J., Anderson R.E. (2014) Multivariate Data Analysis (7th ed.). Harlow (UK): Pearson Education Limited.

Hambrick D.C., Mason P.A. (1984) Upper Echelons: The Organization as a Reflection of Its Top Managers. Academy of Management Review, vol. 9, no 2, pp. 193-206.

Harrigan P., Ramsey E., Ibbotson P. (2011) Critical factors underpinning the e-CRM activities of SMEs. Journal of Marketing Management, vol. 27, no 5-6, pp. 503-529. 
Hernandez-Carrion C., Camarero-Izquierdo C., Gutierrez-Cillian J. (2017) Entrepreneurs`social capital and the economic performance of small businesses: The moderating role of competitive intensity and entrepreneurs' experience. Strategic Entrepreneurship Journal, vol. 11, no 1, pp. 61-89.

Hitt M.A., Ahlstrom D., Dacin M.T., Levitas E., Svobodina L. (2004) The institutional effects on strategic alliance partner selection in transition economies: China vs. Russia. Organization Science, vol. 15, no 2, pp. 173-185.

Hitt M.A., Ireland R.D., Hoskisson R.E. (2016) Strategic Management, Competitiveness and Globalization: Concepts and Cases (12th ed.), Boston, MA: Cengage Learning.

Hoskisson R.E., Hitt M.A., Wan W.P., Yiu D. (1999) Theory and research in strategic management: Swings of a pendulum. Journal of Management, vol. 25, no 3, pp. 417-456.

HSE (2008) Rossiiskaya promyshlennost' na etape rosta: faktory konkurentosposobnosti firm [Russian industry at the stage of growth: Factors of firms' competitiveness] (eds. K. Gonchar, B. Kuznetsov), Moscow: Vershina (in Russian).

HSE (2014) Ocherki modernizatsii rossijskoj promyshlennosti: povedenie firm [Essays on the Modernization of Russian Industry: Behavior of Firms] (ed. B. Kuznetsov), Moscow: HSE (in Russian).

Hurley C.O. (2018) MSME competitiveness in small island economies: A comparative systematic review of the literature from the past 24 years. Entrepreneurship and Regional Development, vol. 30, no 9-10, pp. 1027-1068.

Jarillo J.C. (1988) On strategic networks. Strategic Management Journal, vol. 9, no 1, pp. 31-41.

Julien P.A., Ramangalahy C. (2003) Competitive strategy and performance of exporting SMEs: An empirical investigation of the impact of their export information search and competencies. Entrepreneurship Theory and Practice, vol. 27, no 3, pp. 227-245.

Kapasuwan S., Rose J., Tseng C-H. (2007) The synergistic effects of strategic flexibility and technological resources on performance of SMEs. Journal of Small Business and Entrepreneurship, vol. 20, no 3, pp. 257-272.

Kingsley G., Malecki E.J. (2004) Networking for Competitiveness. Small Business Economics, vol. 23, no 1, pp. 71-84.

Knight G. (2000) Entrepreneurship and marketing strategy: The SME under globalization. Journal of International Marketing, vol. 8, no 2, pp. 12-32.

Kuznetsov B., Dolgopyatova T., Gimpelson V., Golikova V., Gonchar K., Yakovlev A., Yasin Y. (2011) Russian manufacturing revisited: Industrial enterprises at the start of the crisis. Post-Soviet Affairs, vol. 27, no 4, pp. 366-386.

Kuzyk M.G., Simachev Yu.V., Fedyunina A.A. (2020) Spetsifika uchastiya v mezhdunarodnoi torgovle malykh i srednikh bystrorastushchikh firm, vozmozhnye sledstviya dlya gosudarstvennoi politiki [Participation of fast-growing SMEs in international trade and implications for public policy]. Zhurnal Novoj ekonomicheskoj assotsiatsii [Journal of the New Economic Association], no 1, pp. 208-218 (in Russian).

Lafuente E., Leiva J.C., Moreno-Gómez J., Szerb L. (2019) A non-parametric analysis of competitiveness efficiency: The relevance of firm size and the configuration of competitive pillars. Business Research Quarterly (in press). First published online 07.02.2019. Available at: https://doi.org/10.1016/j.brq.2019.02.002, accessed 19.05.2020.

Lagutaeva D., Tretyak O., Grigoriev A. (2016) Vliyanie marketingovykh praktik na pribyl'nost' kompanii: issledovanie metodom mashinnogo obucheniya [Marketing Practices and Profitability of a Company: A Study by Machine Learning Method]. Rossiiskii zhurnal menedzhmenta [Russian Management Journal], vol. 14, no 4, pp. 3-20 (in Russian).

Lazzarini S.G. (2015) Strategizing by the government: Can industrial policy create firm-level competitive advantage? Strategic Management Journal, vol. 36, no 1, pp. 97-112.

Lu J.W., Beamish P.W. (2001) The internationalization and performance of SMEs. Strategic Management Journal, vol. 22, no 6-7, pp. 565-586.

Man T.W.Y, Lau T., Snape E. (2008) Entrepreneurial competencies and the performance of small and medium enterprises: An investigation through a framework of competitiveness. Journal of Small Business and Entrepreneurship, vol. 21, no 3, pp. 257-276.

Man T.W.Y., Lau T., Chan K.F. (2002) The competitiveness of small and medium enterprises: A conceptualization with focus on entrepreneurial competencies. Journal of Business Venturing, vol. 17, no 2, pp. 123-142.

Martin D., Romero I., Wegner D. (2019) Individual, Organizational, and Institutional Determinants of Formal and Informal Inter-firm Cooperation in SMEs. Journal of Small Business Management, vol. 57, no 4, pp. 1698-1711.

May R.C., Stewart W.H. (Jr.), Sweo R. (2000) Environmental scanning behavior in a transitional economy: Evidence from Russia. Academy of Management Journal, vol. 43, no 3, pp. 403-427.

McMahon R.G.P. (2001) Business growth and performance and the financial reporting practices of Australian Manufacturing SMEs. Journal of Small Business Management, vol. 39, no 2, pp. 152-164.

Mesquita L.F., Lazzarini S.G. (2008) Horizontal and vertical relationships in developing economies: Implications for SMEs` access to global markets. Academy of Management Journal, vol. 51, no 2, pp. 359-380.

Meyer K.E., Peng M.W. (2016) Probing theoretically into Central and Eastern Europe: Transactions, resources, and institutions. Journal of International Business Studies, vol. 36, no 6, pp. 600-621. 
Ngo V.D., Janssen F. (2016) Resources investment and export competitive advantage of firms in a transition economy: the moderating role of domestic institutional environment and competitive pressures. International Journal of Export Marketing, vol. 1, no 2, pp. 166-192.

Nguyen T.H., Newby M., Macaulay M.J. (2015) Information technology adoption in small business: Confirmation of a proposed framework. Journal of Small Business Management, vol. 53, no 1, pp. 207-227.

O'Cass A., Weerawardena J. (2010) The effects of perceived industry competitive intensity and marketing-related capabilities: Drivers of superior brand performance. Industrial Marketing Management, vol. 39, no 4, pp. 571-581.

OECD (2015) Russian Federation: Key Issues and Policies (Series: OECD Studies on SMEs and Entrepreneurship), Paris: OECD.

OECD (2017) Small, Medium, Strong. Trends in SME Performance and Business Conditions, Paris: OECD.

Partanen J., Kauppila O.-P., Sepulveda F., Gabrielsson M. (2018) Turning strategic network resources into performance: The mediating role of network identity of small- and medium-sized enterprises. Strategic Entrepreneurship Journal (in press). First published online 04.06.2018. Available at: https://doi.org/10.1002/sej.1296, accessed 19.05.2020.

Pavitt K. (1984) Sectoral patterns of technical change: Towards a taxonomy and a theory. Research Policy, vol. 13, no 6, pp. 343-373.

Pergelova A., Manolova T., Simeonova-Ganeva R., Yordanova D. (2019). Democratizing Entrepreneurship? Digital technologies and the internationalization of female-led SMEs. Journal of Small Business Management, vol. 57, no 1, pp. 14-39.

Peteraf M.A., Bergen M.E. (2003) Scanning dynamic competitive landscapes: A market-based and resource-based framework. Strategic Management Journal, vol. 24, no 10, pp. 1027-1041.

Porac J.F., Thomas H. (1990) Taxonomic mental models in competitor definition. Academy of Management Review, vol. 15, no 2, pp. 224-240.

Porac J.F., Thomas H., Baden-Fuller C. (1989) Competitive groups as cognitive communities: The case of Scottish knitwear manufacturers. Journal of Management Studies, vol. 26, no 4, pp. 397-416.

Porter M. (1980) Competitive strategy: Techniques for analyzing industries and competitors, New York: Free Press.

Porter M., Millar V. (1985) How information gives you competitive advantage. Harvard Business Review, vol. 63, no 4, pp. 149-160.

Porter M.E. (1985) Competitive Advantage: Creating and Sustaining Superior Performance, New York: Free Press.

Prahalad C.K., Hamel G. (1990) The core competence of the corporation. Harvard Business Review, vol. 68, no 3, pp. 79-91.

Puffer S.M., McCarthy D.J. (2011) Two decades of Russian business and management research: An institutional theory perspective. Academy of Management Perspectives, vol. 25, no 2, pp. 21-36.

Puffer S.M., McCarthy D.J., May R.C., Shirokova G.V., Panibratov A. (2018) Managing Emerging Markets in Russia. The Oxford Handbook of Management in Emerging Markets (eds. R. Grosse, K.E. Meyer), New York: Oxford University Press, pp. 703-725.

Radas S., Božić L. (2009) The antecedents of SME innovativeness in an emerging transition economy. Technovation, vol. 29, no 6-7, pp. 438-450.

Raymond L., Bergeron F., Croteau A.-M., St-Pierre J. (2015) Developing absorptive capacity through e-business: The case of international SMEs. Journal of Small Business Management, vol. 53, no S1, pp. 75-94.

Raymond L., Bergeron F., Croteau A.-M., St-Pierre J. (2016) IT-enabled Knowledge Management for the Competitive Performance of Manufacturing SMEs: An Absorptive Capacity-based View. Knowledge and Process Management, vol. 23, no 2, pp. 110-123.

Rebiazina V., Smirnova M., Kouchtch S. (2013) Portfel'nyi i evolyutsionnyi podkhody k postroeniyu vzaimootnoshenii rossiiskikh kompanii s partnerami [Portfolio and Evolutionary Approaches to Building Relationships with Partners: The Case of Russian Companies]. Rossiiskii zhurnal menedzhmenta [Russian Management Journal], vol. 11, no 3, pp. 31-52 (in Russian).

Rivard S., Raymond L., Verreault D. (2006) Resource-based view and competitive strategy: An integrated model of the contribution of information technology to firm performance. Journal of Strategic Information Systems, vol. 15, no 1, pp. 29-50.

Sauka A., Chepurenko A. (2017) Entrepreneurship in Transition Economies: Diversity, Trends, and Perspectives, Heidelberg; New York; Dordrecht; London: Springer.

Shakina E., Barajas A., Molodchik M. (2017) Bridging the gap in competitiveness of Russia companies with intangible bricks. Measuring Business Excellence, vol. 21, no 1, pp. 86-100.

Shirokova G., Vega G., Sokolova L. (2013) Performance of Russian SMEs: Exploration, exploitation and strategic entrepreneurship. Critical Perspectives on International Business, vol. 9, no 1-2, pp. 173-203.

Simachev Y., Kuzyk M. (2017) Vliyanie gosudarstvennykh institutov razvitiya na innovatsionnoe povedenie firm: kachestvennye effekty [The impact of state development institutions on the innovative behavior of firms: qualitative effects]. Voprosy Ekonomiki, no 2, pp. 109-135 (in Russian). 
Simachev Y., Kuzyk M., Zudin N. (2016) Import Dependence and Its Substitution in the Russian Manufacturing: Business Viewpoint. Foresight and STI Governance, vol. 10, no 4, pp. 25-45. DOI: 10.17323/1995-459X.2016.4.25.45.

Sokolov A., Rudnik P. (2014) Innovation in Russian SMEs: Growth under Transition. The Promise of Small and Medium Enterprises (eds. A. Arroio, M. Scerri), New Delhi: Routledge, pp. 76-118.

Spanos Y.E., Lioukas S. (2001) An examination into the causal logic of rent generation: Contrasting Porter's competitive strategy framework and the resource-based perspective. Strategic Management Journal, vol. 22, no 10, pp. 907-934.

St-Pierre J., Sakka O., Bahri M. (2018) External financing, export intensity and inter-organizational collaborations: Evidence from Canadian SMEs. Journal of Small Business Management, vol. 56, no S1, pp. 68-87.

Street C.T., Cameron A-F. (2007) External relationships and the small business: A review of small business alliance and network research. Journal of Small Business Management, vol. 45, no 2, pp. 239-266.

Tretyak O., Rebiazina V., Vetrova T. (2015) Sovremennye marketingovye praktiki v Rossii: Rezul'taty empiricheskogo issledovaniya [Contemporary Marketing Practices in Russia: Results of Empirical Study]. Rossiiskii zhurnal menedzhmenta [Russian Management Journal], vol. 13, no 1, pp. 3-26 (in Russian).

Volchek D., Jantunen A., Saarenketo S. (2013) The institutional environment for international entrepreneurship in Russia: Reflections on growth decisions and performance in SMEs. Journal of International Entrepreneurship, vol. 11, no 4, pp. 320-350.

Welter F. (2011) Contextualizing entrepreneurship - conceptual challenges and ways forward. Entrepreneurship Theory and Practice, vol. 35, no 1, pp. 165-184.

Welter F., Smallbone D. (2011) Institutional perspectives on entrepreneurial behavior in challenging environments. Journal of Small Business Management, vol. 49, no 1, pp. 107-125.

Wernerfelt B. (1984) A resource-based view of the firm. Strategic Management Journal, vol. 5, no 2, pp. 171-180.

Wu J., Pangarkar N. (2010) The bidirectional relationship between competitive intensity and collaboration: Evidence from China. Asia Pacific Journal of Management, vol. 27, pp. 503-522.

Zahra S.A. (1996) Technology strategy and financial performance: Examining the moderating role of the firm 's competitive environment. Journal of Business Venturing, vol. 11, no 3, pp. 189-219. 